Doi: HTTPS://DOI.ORG/10.23910/IJBSM/2017.8.4.1818g

\title{
Performance of MGNREGS - Aquaculture Convergence: A Study in Tripura, India
}

\author{
R. S. ljardar, A. Sarkar*, A. D. Upadhyay, P. Biswas and Y. J. Singh
}

College of Fisheries, CAU (Imphal), Lembucherra, Tripura (799 210), India

\section{Corresponding Author}

A. Sarkar

e-mail: atanusarkar.1954@gamail.com

\author{
Article History \\ Article ID: AR1818g \\ Received in $16^{\text {th }}$ June, 2017 \\ Received in revised form $29^{\text {th }}$ July, 2017 \\ Accepted in $5^{\text {th }}$ August, 2017
}

\begin{abstract}
The paper is based on a study conducted in northeastern state of Tripura (India) to comprehend intra-state level performance of work execution relating to excavation and reclamation of ponds under MGNREGS during 2012-13 to 2016-17; and to examine the performance of those built up aquatic resources during post work execution phase. At first phase, analysis of secondary data revealed that the state had executed 82628 nos. of works combining both pond excavation and reclamation jobs during the period under study, of which the share of works on excavation of new ponds and reclamation of existing ones was $65.26 \%$ and $34.74 \%$ respectively. Signifying possible influence of MGNREGS through such works, while the area under culture fisheries in Tripura registered $7.11 \%$ gain during the period, in case of fish production from culture fisheries $18.02 \%$ gain was recorded. At the second phase, examination of the performance of post work execution period through a case study conducted in West Tripura district over 65 nos. of MGNREGS beneficiaries, however, revealed that although $81.54 \%$ of them had no previous experience of culture fisheries as they became first ever owners of pond, there remained extreme inadequacy in pertaining enabling skill training to them to pursue scientific aquaculture. And that had led to their very poor extent of adoption (29.57\%) of scientific aquaculture practices to, in turn, poor accrual of annual fish productivity $\left(735.58 \mathrm{~kg} \mathrm{ha}^{-1}\right)$ by them that lagged by 3.3 times from the state average and 3.6 times from the average of West Tripura district, where the study was conducted.
\end{abstract}

Keywords: MGNREGS, aquaculture, post execution convergence, adoption, training, Tripura

\section{Introduction}

In India, a land mark beginning to ensure social protection, livelihood security, inclusive growth and democratic empowerment of its poor people living in the rural nexus was made through introduction of the National Rural Employment Guarantee Act (NREGA) on September 7, 2005. Subsequently, on October 2, 2009, it was renamed as the Mahatma Gandhi National Rural Employment Guarantee Act (MGNREGA). The MGNREGA was made effective in the form of Mahatma Gandhi National Rural Employment Guarantee Scheme (MGNREGS) and was classified as a Centrally Sponsored Scheme. The Act provided a legal guarantee for 100 days of wage employment in a year to every rural household whose adult members would volunteer to do unskilled manual work. (Ministry of Rural Development, Gol, 2013). The delineation of the scheme suggested that on completion of the works undertaken, there would be creation of durable assets at local levels to act as long term livelihood resource base for strengthening future economic activities of the rural poor. Among many other permissible works included in the scope of the scheme, provisions were also kept for excavation of farm ponds and renovation of traditional water bodies including de-silting of tanks. Alongside provisioning for such works, the issue of convergence was also duly paid heed to. And here, it was specifically conceived that in case of works completed under MGNREGS by way of creation of assets like newly dug out ponds and renovation of traditional water bodies, including de-silting of tanks, those assets would be taken care of in terms of both fund as well as technical expertise and knowhow support through convergence with the resources of other programmes/schemes available with panchayats and other line departments of the concerned states to facilitate securing of livelihood of the beneficiary rural households as part of effective management of post work execution phase. (Ministry of Rural Development, Gol, 2013).

Fishery occupies a unique place among the people of tiny northeastern state Tripura, which covers an area of 10,491 $\mathrm{km}^{2}$ and support 36,71,032 population (Census of India, 2011). Here, fish is one of the most important constituent of daily diet for $95 \%$ of its population. Considering importance of fish as one of the sources of household nutrition, the state had adopted two pronged strategy in the form of both vertical as well as horizontal expansion of aquaculture sector (Department of Fisheries, Govt. of Tripura, 2014). While productivity enhancement of available water bodies through 
scientific fish culture was assumed to facilitate vertical expansion, the horizontal expansion on the other hand was envisioned to be achieved through increasing the present area under culture fisheries through converging resources of relevant schemes/programmes. It was also emphasized to revivify the existing unproductive water bodies through due reclamation. And utilization of MGNREGS fund is being made by the state for such purposes. So, the present study was conducted to i] comprehend intra-state level performance of work execution relating to excavation and reclamation of ponds under MGNREGS during 2012-13 to 2016-17; and ii] to examine the performance of those built up aquatic resources during post work execution phase.

\section{Materials and Methods}

\subsection{Study sites}

The study was conducted in the north-eastern state of Tripura (India) during September, 2016 - February, 2017. The first objective was addressed using secondary data. For attaining the second objective, a case study was conducted in the randomly pooled five out of total eight blocks of West Tripura district. While selecting the villages from the chosen blocks, based upon the criteria where reasonable number of excavation/reclamation works of water bodies was done under MGNREGS support during 2012-13 and 2016-17, firstly five separate list of all such villages for each of the five blocks were prepared through taking assistance from the official website of the scheme as well as key informants. Secondly, from each of those five lists, two villages were randomly chosen. Accordingly, ten villages found selection. Finally, 65 nos. of MGNREGS supported pond owning aquaculturists were pooled from those villages through probability proportionate to size sampling.

\subsection{Method of data collection}

The first objective was addressed using secondary data available with different public domains including website of the scheme (www.nrega.nic.in.). For collecting primary data from MGNREGS supported aquaculturists, however, pre-tested structured interview schedule was prepared and employed. For examining the second objective, four parameters were identified viz. fish productivity since initiation of culture fisheries in MGNREGS supported ponds; extent of adoption of scientific aquaculture practices; annual income from the scheme supported ponds and surroundings; and training exposure on scientific aquaculture practices. For computing average annual fish productivity, firstly culture period vis-a-vis study period wise combined production performances of fish for each respondent was determined and then the mean value at aggregate level for the entire study period was calculated to finally estimate the annual values in $\mathrm{kg} \mathrm{ha}^{-1}$. For ascertaining the extent of adoption of scientific aquaculture practices, the scale developed by Saha et al. (2010) was utilized. The scale consisted 18 critical sub-activities distributed against six major domains of activities like - pond preparation (contained four critical sub-activities); pond liming (contained two critical subactivities); manuring and fertilization of the pond (contained three critical sub-activities); stocking (contained four critical sub-activities); supplementary feeding (contained three critical sub-activities); and water exchange and quality monitoring (contained two critical sub-activities). On the basis of adoption score, adoption index was computed for all six major domains of activities using following formula:

Adoption index Mean score obtained in a particular domain

Maximum obtainable score in that domain

Calculation of overall adoption index was done in following manner:

Overall adoption index $=\frac{\begin{array}{c}\text { Adoption score obtained } \\ \text { combining all domains }\end{array}}{\begin{array}{c}\text { Maximum obtainable score } \\ \text { combining all domains }\end{array}} \times 100$

The annual income from MGNREGS supported water bodies and surroundings was computed in terms of average annual income accrued through both culture fisheries

The annual income from MGNREGS supported water bodies and surroundings was computed in terms of average annual income accrued through both culture fisheries as well as pond dyke and trellis based small horticulture and/or raising plantation crops. Side by side, their distributive pattern across various income range categories was also worked out.

\section{Results and Discussion}

\subsection{Physical performance of MGNREGS supported pond excavation/reclamation works}

In terms of year wise physical performance of works relating to excavation of new ponds and reclamation of existing ponds across various constituent districts of Tripura, Table 1 had revealed that during 2012-13 financial year highest number of such works was executed in the Dhalai district (3013 nos.) and in descending order the next eight districts were Khowai (2849 nos.), Gomati (2570 nos.), North Tripura (2427 nos.), West Tripura (1933), Sepahijala (1574 nos.), South Tripura (1407 nos.), and Unokoti (1090 nos.). Consequently, a total of 17068 nos. of works relating to excavation and reclamation of ponds could be executed in the state with shares of new pond excavation works being $67.14 \%$ and the rest $32.86 \%$ by reclamation of existing ones. In 2013-14 financial year, the standing of various districts in terms of such physical performance were West Tripura (3489 nos.), Dhalai (3743 nos.), North Tripura (3284 nos.), Gomati (3273 nos.), Khowai (2896 nos.), Sepahijala (2676 nos.), South Tripura (1947 nos.), and Unokoti (1090 nos.). It needs a mention here that though there occurred an increase in the physical performance from the previous year, the district of Khowai, nevertheless, relegated to fifth position in 2013-14, whereas the West Tripura district assumed the top position by virtue 


\begin{tabular}{|c|c|c|c|c|c|c|c|c|}
\hline \multirow[t]{2}{*}{ District } & \multirow[t]{2}{*}{ Year } & \multicolumn{2}{|c|}{$\begin{array}{c}\text { Excavation of new } \\
\text { ponds }\end{array}$} & \multicolumn{2}{|c|}{$\begin{array}{l}\text { Reclamation of existing } \\
\text { ponds }\end{array}$} & \multicolumn{3}{|c|}{ All works combined } \\
\hline & & No. & $\%$ & No. & $\%$ & No. & $\%$ & Overall rank \\
\hline \multirow{6}{*}{ West Tripura } & $2012-13$ & 1033 & 53.44 & 900 & 46.56 & 1933 & 16.47 & \\
\hline & 2013-14 & 2028 & 58.13 & 1461 & 41.87 & 3489 & 29.73 & \\
\hline & 2014-15 & 2214 & 62.74 & 1315 & 37.26 & 3529 & 30.07 & \\
\hline & $2015-16$ & 1370 & 62.67 & 816 & 37.33 & 2186 & 18.62 & \\
\hline & $2016-17$ & 321 & 53.50 & 279 & 46.50 & 600 & 5.11 & \\
\hline & Total & 6966 & 59.35 & 4771 & 40.65 & 11737 & 100.00 & IV \\
\hline \multirow[t]{6}{*}{ Dhalai } & $2012-13$ & 2533 & 84.07 & 480 & 15.93 & 3013 & 21.35 & \\
\hline & 2013-14 & 3122 & 83.41 & 621 & 16.59 & 3743 & 26.52 & \\
\hline & $2014-15$ & 3976 & 80.67 & 951 & 19.30 & 4927 & 34.91 & \\
\hline & $2015-16$ & 1199 & 73.78 & 426 & 26.22 & 1625 & 11.51 & \\
\hline & $2016-17$ & 579 & 71.84 & 227 & 28.16 & 806 & 5.71 & \\
\hline & Total & 11409 & 80.83 & 2705 & 19.17 & 14114 & 100.00 & 1 \\
\hline \multirow[t]{6}{*}{ Gomati } & $2012-13$ & 1549 & 60.27 & 1021 & 39.73 & 2570 & 21.74 & \\
\hline & 2013-14 & 2016 & 61.59 & 1257 & 38.41 & 3273 & 27.68 & \\
\hline & 2014-15 & 2178 & 59.25 & 1498 & 40.75 & 3676 & 31.09 & \\
\hline & 2015-16 & 1002 & 48.71 & 1055 & 51.29 & 2057 & 17.40 & \\
\hline & $2016-17$ & 160 & 64.52 & 88 & 35.48 & 248 & 2.10 & \\
\hline & Total & 6905 & 58.40 & 4919 & 41.60 & 11824 & 100.00 & ॥ \\
\hline \multirow[t]{6}{*}{ Khowai } & $2012-13$ & 1675 & 58.79 & 1174 & 41.21 & 2849 & 24.15 & \\
\hline & 2013-14 & 1613 & 55.70 & 1283 & 44.30 & 2896 & 24.56 & \\
\hline & 2014-15 & 1915 & 52.93 & 1703 & 47.07 & 3618 & 30.68 & \\
\hline & $2015-16$ & 1165 & 57.85 & 849 & 42.15 & 2014 & 17.08 & \\
\hline & $2016-17$ & 233 & 56.01 & 183 & 43.99 & 416 & 3.53 & \\
\hline & Total & 6601 & 55.97 & 5192 & 44.03 & 11793 & 100.00 & III \\
\hline \multirow[t]{6}{*}{ North Tripura } & $2012-13$ & 1602 & 66.01 & 825 & 33.99 & 2427 & 22.14 & \\
\hline & 2013-14 & 2445 & 74.45 & 839 & 25.55 & 3284 & 29.96 & \\
\hline & 2014-15 & 1875 & 66.23 & 956 & 33.77 & 2831 & 25.83 & \\
\hline & $2015-16$ & 1107 & 57.30 & 825 & 42.70 & 1932 & 17.63 & \\
\hline & $2016-17$ & 324 & 66.67 & 162 & 33.33 & 486 & 4.43 & \\
\hline & Total & 7353 & 67.09 & 3607 & 32.91 & 10960 & 100.00 & V \\
\hline \multirow[t]{6}{*}{ Sepahijala } & $2012-13$ & 1015 & 64.49 & 559 & 35.51 & 1574 & 17.25 & \\
\hline & 2013-14 & 1430 & 53.44 & 1246 & 46.56 & 2676 & 29.32 & \\
\hline & 2014-15 & 1362 & 54.74 & 1126 & 45.26 & 2488 & 27.26 & \\
\hline & $2015-16$ & 1109 & 60.04 & 738 & 39.96 & 1847 & 20.24 & \\
\hline & $2016-17$ & 376 & 69.50 & 165 & 30.50 & 541 & 5.93 & \\
\hline & Total & 5292 & 57.99 & 3834 & 42.01 & 9126 & 100.00 & $\mathrm{VI}$ \\
\hline
\end{tabular}




\begin{tabular}{|c|c|c|c|c|c|c|c|c|}
\hline \multirow[t]{2}{*}{ District } & \multirow[t]{2}{*}{ Year } & \multicolumn{2}{|c|}{$\begin{array}{c}\text { Excavation of new } \\
\text { ponds }\end{array}$} & \multicolumn{2}{|c|}{$\begin{array}{c}\text { Reclamation of existing } \\
\text { ponds }\end{array}$} & \multicolumn{3}{|c|}{ All works combined } \\
\hline & & No. & $\%$ & No. & $\%$ & No. & $\%$ & Overall rank \\
\hline \multirow[t]{6}{*}{ South Tripura } & $2012-13$ & 1018 & 72.35 & 389 & 27.65 & 1407 & 17.13 & \\
\hline & 2013-14 & 1145 & 58.81 & 802 & 41.19 & 1947 & 23.71 & \\
\hline & 2014-15 & 2067 & 67.75 & 984 & 32.25 & 3051 & 37.15 & \\
\hline & $2015-16$ & 864 & 65.50 & 455 & 34.50 & 1319 & 16.06 & \\
\hline & $2016-17$ & 309 & 63.32 & 179 & 36.68 & 488 & 5.94 & \\
\hline & Total & 5403 & 65.79 & 2809 & 34.21 & 8212 & 100.00 & VII \\
\hline \multirow[t]{6}{*}{ Unokoti } & $2012-13$ & 1034 & 79.85 & 261 & 20.15 & 1295 & 26.63 & \\
\hline & 2013-14 & 876 & 80.37 & 214 & 19.63 & 1090 & 22.42 & \\
\hline & $2014-15$ & 563 & 74.47 & 193 & 25.53 & 756 & 15.55 & \\
\hline & $2015-16$ & 1311 & 90.73 & 134 & 9.27 & 1445 & 29.72 & \\
\hline & $2016-17$ & 214 & 77.54 & 62 & 22.46 & 276 & 5.68 & \\
\hline & Total & 3998 & 82.23 & 864 & 17.77 & 4862 & 100.00 & VIII \\
\hline \multirow[t]{6}{*}{ Tripura } & $2012-13$ & 11459 & 67.14 & 5609 & 32.86 & 17068 & 20.65 & \\
\hline & 2013-14 & 14675 & 65.52 & 7723 & 34.48 & 22398 & 27.11 & \\
\hline & 2014-15 & 16150 & 64.92 & 8726 & 35.08 & 24876 & 30.11 & \\
\hline & $2015-16$ & 9127 & 63.27 & 5298 & 36.73 & 14425 & 17.46 & \\
\hline & 2016-17 & 2516 & 65.16 & 1345 & 34.84 & 3861 & 4.67 & \\
\hline & Total & 53927 & 65.26 & 28701 & 34.74 & 82628 & 100.00 & \\
\hline
\end{tabular}

Source: Authors' own calculation based on information available from official website of the Ministry of Rural Development, Government of India for 2012-13 to 2016-17 on MGNREGA http://mnregaweb4.nic.in/netnrega/writereaddata/citizen_out/ wrkstatlink_30_05_1314 ALL. html

of registering almost $80.50 \%$ increase over its previous year's performance. In 2014-15, the districts of Dhalai, Gomati, Khowai and West Tripura had assumed the first four positions in terms of such work accomplishments with the number of works therein being 4927 nos., 3676 nos., 3618 nos. and 3529 nos. respectively. And, in order of descend, the other districts were South Tripura (3051 nos.), North Tripura (2831 nos.), Sepahijala (2488 nos.), and Unokoti (756 nos.). Thus, the state could altogether execute 24876 nos. of excavation and reclamation works in that year with the shares of new pond excavation works being $64.92 \%$ and the rest $35.08 \%$ by reclamation of existing ones.

But, in contrast to the previous year, the Dhalai district was slipped to seventh position in 2015-16 with its works accomplishment rate being 1625 nos. Rather, the first four positions in that year were assumed by the districts of West Tripura (2186 nos.), Gomati (2057 nos.), Khowai (2014 nos.) and North Tripura (1932 nos.). It is to be noted here that, as compared to the previous three years, the financial year 201516 underwent a phase of decline in terms of execution of such works, excepting in case of the Unokoti district which, with 1445 nos. of works execution, registered a highly appreciative gain of $91.14 \%$ than its previous year's accomplishment of 756 nos. of works. Further, for the whole of the state of Tripura, there occurred a sharp decline to the tune of around $42.00 \%$ in works accomplishment rate with respect to excavation and reclamation of ponds from that of the previous year. But, despite such decline, out of a total of 14425 nos. of works executed in 2015-16 across the state, the shares of new pond excavation works, nevertheless, remained to be at much higher side $(63.27 \%)$ as against $36.73 \%$ share occupied by the reclamation works. Such declining trend had continued in 2016-17 too throughout all the districts of the state. Though, the districts of Dhalai and West Tripura maintained their higher performance graphs by way of retaining top two positions among the districts in terms of physical performance of excavation/reclamation works, the corresponding physical figure, however, drastically reduced in those cases to only 806 nos. and 600 nos. for Dhalai and West Tripura respectively. And in that year, the third and fourth positions were occupied by the districts of Sepahijala (541 nos.) and South Tripura (488 nos.), which had also substantially fell short of the performances therein in the previous years. As the resultant effect, the number of executed works for whole of the state had come down to only 3861 nos. in 2016-17. In terms of overall performances combining all the constituent years under study, Dhalai district ranked first and it was followed in descending order by Gomati, Khowai, West Tripura, North 
Tripura, Sepahijala, South Tripura and Unokoti districts. Finally, by number, the state of Tripura executed 82628 nos. of works combining both pond excavation and reclamation jobs during the period between 2012-13 and 2016-17. And out of that, the share of works relating to excavation of new ponds was $65.26 \%$ as against $34.74 \%$ for the works relating to reclamation of existing water bodies.

Contextual to such revelation, there arose no denying the fact that the state had been keeping due thrust on creation of new ponds so as to pave the way for horizontal expansion of the area under aquaculture in a big way by virtue of utilization of the MGNREGS fund. Alongside, it was also appeared that the issue of efficient utilization of the existing water bodies by way of undertaking de-siltation and other associated activities was quite appreciably addressed across the state.

3.2. Status of area, production and productivity of culture fisheries in the state

Table 2 unveiled of the fact that in all the constituent districts of Tripura both area and production under culture fisheries had undergone a steady progressive growth. While the area under culture fisheries in the state went up to attain 26461 ha. in 2015-16 from that of 24704.04 ha. in 2012-13 (i.e. $7.11 \%$ gain), in case of fish production from culture fisheries

Table 2: District wise aggregated area, production and productivity of culture fisheries in Tripura between 2012-13 to $2015-16$

\begin{tabular}{lccc} 
District & $\begin{array}{c}\text { Total area } \\
\text { covered } \\
\text { by culture } \\
\text { fisheries } \\
\text { (ha.) }\end{array}$ & $\begin{array}{c}\text { Total fish } \\
\text { production } \\
\text { from culture } \\
\text { fisheries } \\
\text { (MT) }\end{array}$ & $\begin{array}{c}\text { Av. annual } \\
\text { productivity } \\
\text { in culture } \\
\text { fisheries } \\
\left(\mathrm{kg} \mathrm{ha}^{-1}\right)\end{array}$ \\
\hline West Tripura & 10076.59 & 26706.95 & 2650.40 \\
Dhalai & 15276.54 & 35816.80 & 2344.56 \\
Gomati & 18367.13 & 41644.66 & 2267.35 \\
Khowai & 11346.73 & 31886.55 & 2810.20 \\
North Tripura & 12205.88 & 27900.61 & 2285.83 \\
Shepahijala & 14089.41 & 34772.19 & 2467.97 \\
South Tripura & 12742.13 & 29623.14 & 2324.82 \\
Unokoti & 8060.39 & 19827.87 & 2459.91 \\
All districts & 102164.80 & 248178.77 & 2429.20
\end{tabular}

Source: Authors' own calculation based on Progress Reports on Fisheries from 2012-13 to 2015-16 of the Directorate of Fisheries, Govt. of Tripura; Note: Average annual fish productivity was figured out by combining corresponding data between 2012-13 to 2015-16)

activities it was recorded to be $67552 \mathrm{MT}$ in 2015-16 as compared to that of 57238.8 MT in $2012-13$ (i.e. $18.02 \%$ gain). And here, creation of new water bodies in one hand and de-silting / reclamation of existing water bodies on the other through the aegis of MGNREGS had presumably played a big role.

\subsection{Fish productivity in respondents' water bodies}

Whereas, $49.23 \%$ of the respondents were found to have moderate level of fish productivity, $26.15 \%$ and $24.62 \%$ of them had low and high level of productivity, respectively (Table 3).

However, the genuine point of concern had emanated from the worked out four years' average fish productivity between 2012-13 to 2015-16 for the respondent beneficiaries of

Table 3: Fish productivity of MGNREGS supported water bodies of the respondents

\begin{tabular}{lcccc}
\hline $\begin{array}{l}\text { Fish productivity } \\
\text { category }\end{array}$ & $\begin{array}{c}\text { Frequen- } \\
\text { cy }\end{array}$ & $\begin{array}{c}\text { Percent- } \\
\text { age }\end{array}$ & Mean & S.D. \\
\hline $\begin{array}{l}\text { Low }(<555.29 \mathrm{~kg} \\
\left.\text { ha }{ }^{-1}\right)\end{array}$ & 17 & 26.15 & 735.58 & 180.29 \\
$\begin{array}{l}\text { Moderate (555.29 } \\
\left.-915.87 \mathrm{~kg} \mathrm{ha}^{-1}\right)\end{array}$ & 32 & 49.23 & & \\
$\begin{array}{l}\text { High }(>915.87 \mathrm{~kg} \\
\left.\text { ha }^{-1}\right)\end{array}$ & 16 & 24.62 & & \\
\hline
\end{tabular}

the scheme. Though it appeared to be $735.58 \mathrm{~kg} \mathrm{ha}^{-1}$, still it was lagging behind by a staggering 3.3 times from the state average ( $2429.20 \mathrm{~kg} \mathrm{ha}^{-1}$ ) and even more by 3.6 times from that of West Tripura district $\left(2650.40 \mathrm{~kg} \mathrm{ha}^{-1}\right)$, where the present study was carried out (Table 4).

Such revelation strongly justified the essentiality for undertaking focused intervention in regard to motivation and skill empowerment of the beneficiary pond owners for enabling them to enhance fish productivity in their owned

\begin{tabular}{|c|c|c|c|c|}
\hline \multicolumn{5}{|c|}{$\begin{array}{l}\text { Average annual fish productivity from culture fisheries } \\
\qquad\left(\mathrm{kg} \mathrm{ha}^{-1}\right)^{*}\end{array}$} \\
\hline \multirow[t]{2}{*}{ Tripura } & \multirow{2}{*}{$\begin{array}{l}\text { West } \\
\text { Tripura }\end{array}$} & \multirow{2}{*}{$\begin{array}{l}\text { Ponds of } \\
\text { MGNREGS } \\
\text { beneficiary } \\
\text { respondents }\end{array}$} & \multicolumn{2}{|c|}{ Shortfall } \\
\hline & & & $\begin{array}{c}\text { From } \\
\text { state } \\
\text { average }\end{array}$ & $\begin{array}{c}\text { From } \\
\text { district } \\
\text { average }\end{array}$ \\
\hline 2429.20 & 2650.40 & 735.58 & 3.3 times & 3.6 times \\
\hline
\end{tabular}

*Average annual fish productivity was figured out by combining corresponding data between 2012-13 to 2015-16

ponds at least to the level of state average so as to contribute more significantly in enhancing the production of fish from culture fisheries in the state.

\subsection{Annual income from MGNREGS supported water bodies and surroundings}

Table 5 indicated that the average annual income of the 
respondents was ₹ 18954/- from MGNREGS supported water bodies basically through practicing culture fisheries. Side by side, ₹ 2323/- was appeared to be their average annual income accrual through utilization of pond dykes and embankments by practicing small horticulture and raising plantation crops. In terms of distributive pattern of annual income categories in accordance with the MGNREGS supported ponds, while Table 5 indicated that $35.38 \%$ of the respondents were placed in the category of income range between > ₹ 15000 - ₹ 20000, in descending order the other categories were being occupied by the income ranges of > ₹ $10000-₹ 15000$ (29.23\%), > ₹ 20000 - ₹ 25000 (21.54\%), > ₹ 25000 (9.23\%) and > ₹ 5000 - ₹ 10000 (4.62\%).

Again, with respect to average annual income from the pond surrounding based miscellaneous small production situations, it was noted from Table 5 that majority of the respondents

Table 5: Distribution of respondents according to annual income from MGNREGS supported water bodies and surrounding

\begin{tabular}{cccc}
\hline $\begin{array}{c}\text { Annual income from } \\
\text { water bodies (₹) }\end{array}$ & $\begin{array}{c}\text { Fre- } \\
\text { quency }\end{array}$ & $\%$ & $\begin{array}{c}\text { Average annual } \\
\text { income (₹) }\end{array}$ \\
\hline Up to 5000 & 00 & 0.00 & 18954 \\
$>5000$ to 10000 & 03 & 4.62 & \\
$>10000$ to 15000 & 19 & 29.23 & \\
$>15000$ to 20000 & 23 & 35.38 & \\
$>20000$ to 25000 & 14 & 21.54 & \\
$>25000$ & 06 & 9.23 & \\
\hline
\end{tabular}

Annual income from surrounding (₹)

$\begin{array}{cccc}\text { Up to } 1000 & 13 & 20.00 & 2323 \\ >1000 \text { to } 2000 & 32 & 49.23 & \\ >2000 \text { to } 3000 & 10 & 15.38 & \\ >3000 \text { to } 4000 & 06 & 9.23 \\ >4000 \text { to } 5000 & 04 & 6.15 \\ >5000 & 00 & 0.00 & \end{array}$

(49.23\%) were in the category of income range between $>$ ₹ 1000 - ₹ 20000. And it was followed in decreasing order by income range categories of up to ₹ 1000 (20.00\%), > ₹ $2000-$ ₹ 3000 (15.38\%), > ₹ 3000 - ₹ 4000 (9.23\%) and > ₹4000 - ₹ $5000(6.15 \%)$.

\subsection{Share of fisheries to annual family income}

In terms of share of fisheries to total income of the respondents, $36.92 \%$ of them were in the share range between $20.1-30 \%, 27.69 \%$ in the share range between $30.1-40 \%$, $18.46 \%$ in the range between $10.1-20 \%, 15.39 \%$ in the range between $40.1-50 \%$, and a meager $1.54 \%$ in the $>50 \%$ range (Figure 1).

In terms of annual income flow of the beneficiary respondents from the MGNREGS supported water bodies and surrounding

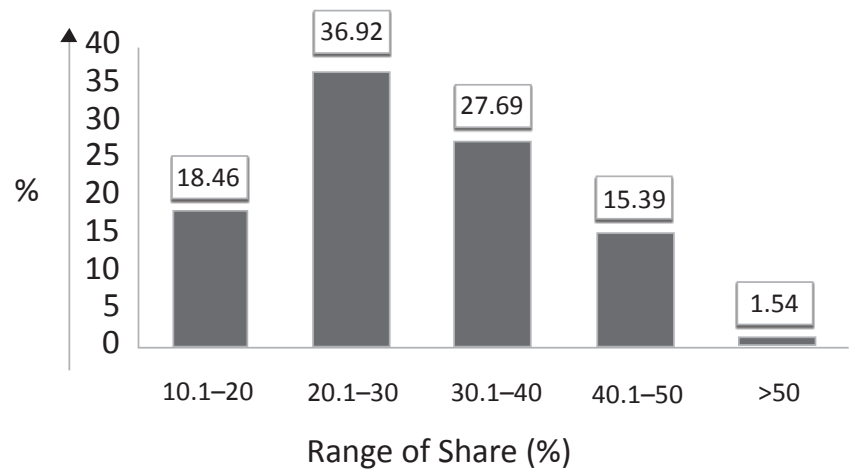

Figure 1 : Percentage share of fisheries to total income of the respondents

land resources, it got revealed from Figure 2 that while $89 \%$ share of the total annual income was deriving from culture fisheries being practiced in the scheme supported water bodies, it was $11.00 \%$ from pond surroundings.

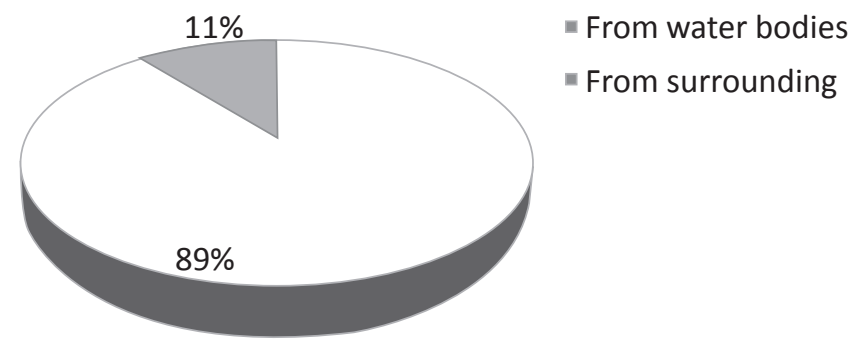

Figure 2: Annual flow of income from MGNREGA supported water bodies and surrounding

\subsection{Extent of adoption of scientific aquaculture practices}

Lamentably, it was noted from Table 6 that for none of the six major domains of activities concerning scientific aquaculture, even $50 \%$ level of adoption could be attained by the beneficiary respondents of the scheme. Though in cases of pond preparation, manuring and fertilization of pond and stocking, the levels of adoption were $42.69 \%, 46.15 \%$ and $43.08 \%$ respectively, the adoption levels were hopelessly poor in cases of the other major domains of activities like pond liming (3.85\%), supplementary feeding (2.56\%) and water exchange and quality monitoring (17.69\%). As the resultant effect, the overall adoption index for whole of the respondents remained to be only $29.57 \%$.

\subsection{Training exposure on scientific aquaculture practices}

In the process of exploring the reason behind such shabby extant scenario of adoption levels, it was revealed that a very high proportion of $81.54 \%$ of the beneficiary respondents became first ever pond owner only after they received the support from MGNREGS (Table 7) and, therefore, were having no previous experience whatsoever as to how to manage the ponds efficiently for ensuring good fish harvest from those 


\begin{tabular}{lcccc}
\hline \multicolumn{5}{l}{ Table 6: Extent of adoption of scientific aquaculture practices } \\
\hline $\begin{array}{l}\text { Sl. } \\
\text { No. }\end{array} \quad \begin{array}{c}\text { Aquaculture } \\
\text { practices }\end{array}$ & $\begin{array}{c}\text { Maximum } \\
\text { obtainable } \\
\text { score }\end{array}$ & $\begin{array}{c}\text { Obtained } \\
\text { score }\end{array}$ & $\begin{array}{c}\text { Adoption } \\
\text { index (\%) }\end{array}$ \\
\hline $\begin{array}{l}\text { 1. } \\
\quad \begin{array}{l}\text { Pond prepara- } \\
\text { tion }\end{array}\end{array}$ & 260 & 111 & 42.69 \\
2. $\quad$ Pond liming & 130 & 05 & 3.85 \\
3. $\quad \begin{array}{l}\text { Manuring and } \\
\text { fertilization of } \\
\text { pond }\end{array}$ & 195 & 90 & 46.15 \\
$\begin{array}{l}\text { 4. Stocking } \\
\text { 5upplementary }\end{array}$ & 195 & 05 & 2.56 \\
$\quad \begin{array}{l}\text { feeding } \\
\text { Water exchange } \\
\text { and quality } \\
\text { monitoring }\end{array}$ & 130 & 23 & 17.69 \\
Overall & 1170 & 346 & 29.57 \\
\hline
\end{tabular}

Table 7: Pond ownership status of respondents before and after MGNREGS intervention

\begin{tabular}{lccccc}
\hline $\begin{array}{l}\text { No. } \\
\text { of re- } \\
\text { spon- }\end{array}$ & $\begin{array}{c}\text { Owned pond prior to } \\
\text { dents }\end{array}$ & & \multicolumn{2}{c}{$\begin{array}{c}\text { Became pond owner } \\
\text { only after MGNREGS } \\
\text { intervention }\end{array}$} \\
\cline { 2 - 3 } \cline { 5 - 6 } & Number & $\%$ & & Number & $\%$ \\
\hline 65 & 12 & 18.46 & & 53 & 81.54 \\
\hline
\end{tabular}

blissful aquatic endowment.

However, Table 8 indicated that although skill enhancement on techniques of efficient management of the ponds and surroundings was essentially required for those mostly new pond owners, the larger proportion (56.92\%) of them did not have the fortune to receive any training exposure during the

Table 8: Training exposure on scientific aquaculture practices

\begin{tabular}{lcc}
\hline Training exposure & Frequency & Percentage \\
\hline Attended training programme & 28 & 43.08 \\
$\begin{array}{l}\text { Area of training } \\
\text { - Scientific fish culture } \\
\quad \text { practices ( } 2 \text { days) }\end{array}$ & $\bullet 22$ & $\bullet 78.57$ \\
$\begin{array}{l}\text { Integrated fish farming } \\
\quad(2 \text { days) }\end{array}$ & $\bullet 06$ & $\bullet 21.43$ \\
$\begin{array}{l}\text { Not attended any training pro- } \\
\text { gramme }\end{array}$ & 37 & 56.92 \\
\hline
\end{tabular}

entire five year span of the study. Against the cases of rest $43.08 \%$ who got training, the duration of all of those courses were of two days only and, hence, should not be expected to effectively inculcate much of the critical skill components to those section of novice fisher folk within that very short span of time frame.

\section{Conclusion}

The stage is set for the state through commendable execution of works concerning creation and reclamation of ponds by utilizing MGNREGS fund. Now, sooner is better would it be to take up measured interventions by the State Fisheries Department in piously organizing in situ demonstrations and skill enabling trainings coupled with technical expertise and knowhow support for enhancing the adoption rate of scientific aquaculture by the beneficiary pond owners and, thus, lead the MGNREGS-Aquaculture convergence process in Tripura towards a real success.

\section{References}

Census of India, 2011. Office of the Registrar General \& Census Commissioner, Ministry of Home Affairs, Government of India, New Delhi.

Department of Fisheries, Govt. of Tripura, 2014. Mandate of the Department. Department of Fisheries, Government of Tripura. Available from http://fisheries.tripura.gov.in/ mandate. htm.

Govt. of Tripura, 2015. Economic Review of Tripura, 201415 (16th issue), Directorate of Economics \& Statistics, Planning (Statistics) Department, Government of Tripura, Agartala, 5. Available from http://www.ecostat.tripura. gov.in.

Ministry of Rural Development, Gol., 2013. Mahatma Gandhi National Rural Employment Guarantee Act, 2005: Operational Guidelines (4th Edn.). Ministry of Rural Development, Department of Rural Development, Govt. of India, New Delhi. Available from http://nrega. nic.in/netnrega/WriteReaddata/Circulars/Operational_ guidelines_4thEdition_eng_2013.pdf.

Ministry of Rural Development, Government of India. 2016. The MGNREGA. Available from http://mnregaweb4.nic.in/ netnrega/writereaddata/citizen_out/wrkstatlink_30_05 _1314 ALL.html.

Saha, B., Singh, N.N., Pandey, D.K., 2010. Knowledge and adoption of improved practices of carp production at Tripura in India. In Intramural Project Report, Central Agricultural University, Imphal, 25-26. 